University of Nebraska - Lincoln

DigitalCommons@University of Nebraska - Lincoln

USGS Staff -- Published Research

US Geological Survey

2012

East versus West: Organic contaminant differences

in brown pelican (Pelecanus occidentalis) eggs from South Carolina, USA and the Gulf of California, Mexico

Stacy S. Vander Pol

Hollings Marine Laboratory

Daniel W. Anderson

University of California-Davis, dwanderson@ucdavis.edu

Patrick G.R. Jodice

Clemson University

Joyce E. Stuckey

College of Charleston

Follow this and additional works at: http://digitalcommons.unl.edu/usgsstaffpub

Part of the Geology Commons, Oceanography and Atmospheric Sciences and Meteorology Commons, Other Earth Sciences Commons, and the Other Environmental Sciences Commons

Vander Pol, Stacy S.; Anderson, Daniel W.; Jodice, Patrick G.R.; and Stuckey, Joyce E., "East versus West: Organic contaminant differences in brown pelican (Pelecanus occidentalis) eggs from South Carolina, USA and the Gulf of California, Mexico" (2012). USGS Staff -- Published Research. 774.

http:// digitalcommons.unl.edu/usgsstaffpub/774

This Article is brought to you for free and open access by the US Geological Survey at DigitalCommons@University of Nebraska - Lincoln. It has been accepted for inclusion in USGS Staff -- Published Research by an authorized administrator of DigitalCommons@University of Nebraska - Lincoln. 


\title{
East versus West: Organic contaminant differences in brown pelican (Pelecanus occidentalis) eggs from South Carolina, USA and the Gulf of California, Mexico
}

\author{
Stacy S. Vander Pol a,*, Daniel W. Anderson ${ }^{\text {b }}$, Patrick G.R. Jodice ${ }^{\text {c }}$, Joyce E. Stuckey ${ }^{\text {d, } 1}$ \\ a National Institute of Standards and Technology, Hollings Marine Laboratory, 331 Fort Johnson Road, Charleston, SC 29412, USA \\ b University of California, Department of Wildlife, Fish, and Conservation Biology, 1081 Academic Surge, Davis, CA 95616, USA \\ c U.S. Geological Survey South Carolina Cooperative Fish and Wildlife Research Unit, G27 Lehotsky Hall, Clemson University, Clemson, SC 29634, USA \\ ' College of Charleston, Grice Marine Laboratory, 205 Fort Johnson Road Charleston, SC 29412, USA
}

\section{H I G H L I G H T S}

- This was the first known analysis of BDEs in the Gulf of California (GofCA).

- Brown pelicans in southeast U.S. (SC) and GofCA have different population trends.

- GofCA eggs had higher levels of lower brominated BDEs than SC; patterns also varied.

- PCBs, chlordanes, dieldrin and mirex were greater in SC eggs; DDTs and $\mathrm{HCH}$ were lower.
G R A P H I C A L A B S T R A C T

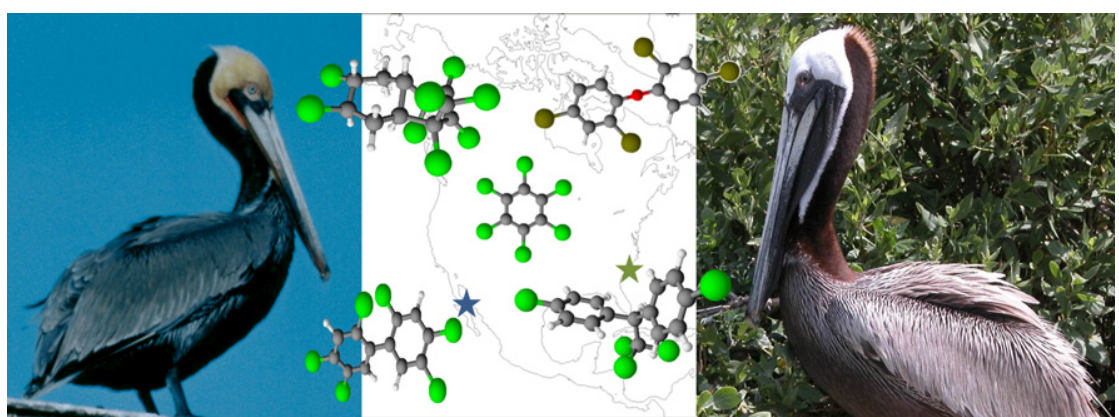

\section{A R T I C L E I N F O}

\section{Article history:}

Received 21 June 2012

Received in revised form 14 August 2012

Accepted 15 August 2012

Available online 2 October 2012

\section{Keywords:}

Brown pelican

Egg

Biomonitor

Polychlorinated biphenyl

Pesticide

Flame retardant

\begin{abstract}
A B S T R A C T
Brown pelicans (Pelecanus occidentalis) were listed as endangered in the United States in 1970, largely due to reproductive failure and mortality caused by organochlorine contaminants, such as DDT. The southeast population, P.o. carolinensis, was delisted in 1985, while the west coast population, P.o. californicus, was not delisted until 2009. As fish-eating coastal seabirds, brown pelicans may serve as a biomonitors. Organic contaminants were examined in brown pelican eggs collected from the Gulf of California in 2004 and South Carolina in 2005 using gas chromatography/mass spectrometry (GC/MS). Contaminants were compared using all individual data as well as statistically pooled samples to provide similar sample sizes with little difference in results. Principal components analysis separated the Gulf of California brown pelican eggs from the South Carolina eggs based on contaminant patterns. The South Carolina population had significantly $(P<0.05)$ higher levels of polychlorinated biphenyls (PCBs), chlordanes, dieldrin and mirex, while the Gulf of California eggs had higher levels of dichlorodiphenyltrichloroethanes (DDTs) and hexachlorocyclohexanes (HCHs). With the exception of dieldrin and brominated diphenyl ether (BDE) 47, this pattern was observed for mussel and oyster tissues from these regions, indicating the need for further study into the differences between east and west coast brown pelican populations and ecosystem contamination patterns.
\end{abstract}

Published by Elsevier B.V.

\footnotetext{
* Corresponding author. Tel.: +1 843762 8994; fax: +1 8437628742

E-mail address: stacy.vanderpol@nist.gov (S.S. Vander Pol).

${ }^{1}$ Currently at Cornell University, Ithaca, NY 14853, USA.
}

\section{Introduction}

In 1970, the brown pelican (Pelecanus occidentalis) was listed as endangered in the United States mainly due to reproductive failure and mortality caused by organochlorine pesticides (Gottschalk and Bureau of Sport Fisheries and Wildlife, Fish and Wildlife Service, Department 
of the Interior, 1970; Bureau of Sport Fisheries and Wildlife, Fish and Wildlife Service, Department of the Interior, 1970). Following the banning of many of these contaminants, the southeast population (P.o. carolinensis) was delisted in 1985 (Potter and Department of the Interior, Fish and Wildlife Service, 1985), but the remaining brown pelicans, including the west coast population (P.o. californicus), were not delisted until 2009 (Eustis and Department of the Interior, Fish and Wildlife Service, 2009). However, since the mid- to late 1980s P.o. carolinensis has experienced several important shifts in its population including an expansion in breeding range to the north, establishment of new colonies in Georgia, and a decline in nesting effort in South Carolina (Jodice et al., 2007; Watts and Byrd, 2006). Meanwhile, recent assessment of nesting effort in the Gulf of California population revealed a steady to increasing trend (Anderson et al., 2007). In both populations, it is unclear what mechanism may be underlying these trends, and it is likely that multiple factors are interacting in each population.

This paper compares data of organochlorine pesticides, polychlorinated biphenyls (PCBs) and brominated diphenyl ethers (BDEs) from east and west coast pelican eggs. Organochlorine pesticides and PCBs were chosen because each was demonstrated to have negatively affected pelican populations prior to listing as endangered species. BDEs, often used as flame retardants, were chosen because they represent a class of contaminants of emerging concern which the US Environmental Protection Agency (EPA) has begun to regulate due to concerns about the toxicity (US Environmental Protection Agency, 2012). As brown pelicans are mainly fish-eating, long-living, coastal birds (Shields, 2002), these contaminants have the ability to bioaccumulate and biomagnify, which helped lead to the detrimental effects previously observed for the population, but also makes them a good biomonitors, not only for the marine environment, but also for humans that live in similar environments and consume similar food (International Council for the Exploration of the Sea (ICES), 2003). Eggs were collected from two colonies of brown pelicans from South Carolina, USA (one located in a national wildlife refuge, the other in a major industrial port) and from three colonies in the Gulf of California, Mexico. While a comparison of egg morphometrics was previously conducted between these populations (Anderson and Hickey, 1970), no known comparison of organic contaminant differences among these populations has not been conducted. The purpose of this study was to determine if contaminant differences exist between the South Carolina and Gulf of California brown pelican populations which may elucidate a potential mechanism underlying current population trends. Where applicable, literature values and toxicological effects are also included to enhance the breadth of the comparisons.

\section{Materials and methods}

\subsection{Sample collection and processing}

\subsubsection{East-South Carolina}

Twenty-eight (28) brown pelican (Pelecanus occidentalis carolinensis) eggs were collected from newly formed nests in May 2005 from two South Carolina colonies: (1) Crab Bank $(n=18)$ in Charleston Harbor $\left(32^{\circ} 46^{\prime} 58.8^{\prime \prime} \mathrm{N}, 79^{\circ} 53^{\prime} 20.4^{\prime \prime} \mathrm{W}\right)$ and (2) Marsh Island $(\mathrm{n}=10)$ in Cape Romain National Wildlife Refuge approximately $35 \mathrm{~km}$ northeast of Charleston, SC ( $32^{\circ}$ 59' 24.0' N, $79^{\circ} 32^{\prime}$ 56.4" W; see Table A1, Supplementary data). Only one egg was collected from each nest, and eggs were only collected from clutches with $\geq 3$ eggs. An attempt was made to spread the collection effort over as wide a portion of the colonies as possible to achieve a representative sample of available eggs. The eggs were floated in water to determine freshness. The eggs that sank were suspected to be in a very early stage of development, while those eggs that floated were older and more developed. Only eggs suspected to still be in the early yolk stage were collected. The eggs were stored in a refrigerator $\left(4^{\circ} \mathrm{C}\right)$ until homogenization using a pre-cleaned hand-held blender (Oster, Shelton, CT, USA) following protocols previously established for the Seabird Tissue Archival and Monitoring Project (STAMP; see Roseneau et al. (2008) and Vander Pol et al. (2009) for further details). Aliquots of the homogenized sample were pipetted with a hexane-rinsed glass pipette into $15 \mathrm{~mL}$ Teflon jars and stored at $-80{ }^{\circ} \mathrm{C}$ until analysis. Aliquots not analyzed were transferred to liquid nitrogen vapor freezers for long-term storage. To test reproducibility, duplicate aliquots from three randomly chosen samples were analyzed.

\subsubsection{West-Gulf of California}

Fifteen (15) brown pelican (P.o. californicus) eggs were collected from active nests in March and April 2004 from three Gulf of California, Mexico colonies: (1) Isla San Luis, Baja California Norte (BCN; $29^{\circ} 58^{\prime}$ $\left.8.4^{\prime \prime} \mathrm{N}, 114^{\circ} 24^{\prime} 3.6^{\prime \prime} \mathrm{W} ; \mathrm{n}=5\right)$, (2) Isla Piojo, BCN (29 $1^{\prime} 1.2^{\prime \prime} \mathrm{N}, 113^{\circ}$ $\left.27^{\prime} 46.8^{\prime \prime} \mathrm{W} ; \mathrm{n}=5\right)$, and (3) Isla San Lorenzo Sur, BCN (28 $40^{\prime} 1.2^{\prime \prime} \mathrm{N}$, $112^{\circ} 52^{\prime} 1.2^{\prime \prime} \mathrm{W} ; \mathrm{n}=5$ ). Colonies ranged from 500 to 15,000 nests in size. To reduce disturbance, sampled sub-colonies were chosen based on the presence of large numbers of eggs in nests (mid- to late-season breeders). Every other nest was sampled with the egg from each nest chosen blindly. Eggs were opened, and contents were homogenized and stored frozen in acetone rinsed glass jars in Ensenada, BCN, Mexico. Based on limited resources at the time of this study and previous studies that have shown limited loss of data for other seabird eggs compared to individual analysis (Sellström et al., 2003; Turle and Collins, 1992), eggs were pooled in sets of three based on number of eggs per clutch, incubation state, and location (see Table A1, Supplementary data for details). Immediately prior to preparation for analysis at NIST in Charleston, SC, USA three eggs were pooled by using a hexane-rinsed stainless steel spatula to remove approximately $2.4 \mathrm{~g}$ of thawed, homogenized sample to a hexane-rinsed glass jar. The pooled sample was stirred with a clean hexane-rinsed stainless steel spatula prior to removing an aliquot for analysis.

While every effort was made to sample eggs that were very early in incubation, the only eggs available for analysis at Isla San Luis in the Gulf of California were incubated to various stages (Table A1, Supplementary data, incubation stage is an approximation factor that should be multiplied by the average incubation of 30 days). For the worst-case (sample CA-3, Table A1, Supplementary data) the calculated expected moisture loss was $5.1 \%$ which is within the analytical variation for the environmental contaminants (Table A2, Supplementary data). Due to the large number of variables involved (variable incubation period, imprecision of stage estimates, etc.) the actual field mass versus the calculated fresh mass were used for all analyses.

\subsection{Sample preparation and analysis}

Approximately $3 \mathrm{~g}$ of material from each of the samples were analyzed using methods previously described by Vander Pol et al. (2009). Briefly, the aliquots were extracted by pressurized fluid extraction (PFE), cleaned up using size-exclusion chromatography (SEC), and analyzed by gas chromatography/mass spectrometry (GC/MS) in two injections. The electron impact (EI) GC/MS injection used a $30 \mathrm{~m} \times 0.18 \mathrm{~mm} \times 0.18 \mu \mathrm{m}$ i.d. DB-5MS column (J\&W Scientific, Folsom, CA, USA) with a $5 \mathrm{~m} \times 0.25 \mathrm{~mm}$ retention gap added to the beginning of the column and the oven ramp described by Vander Pol et al. (2011). All other GC/MS conditions were as described by Vander Pol et al. (2009). The negative chemical ion (NCI) mode injection used a $30 \mathrm{~m} \times 0.18 \mathrm{~mm} \times 0.18 \mu \mathrm{m}$ i.d. DB-XLB column (Agilent, Palo Alto, CA, USA) using the 16 min method described by Vander Pol et al. (2010). Murre Egg Control Material (Vander Pol et al., 2007), procedural blanks, and six calibration solutions were prepared and analyzed along with the egg samples for quality assurance and control.

\subsection{Statistics}

Limits of detection (LODs) were calculated as the maximum of either (1) the lowest observable calibration solution divided by the 
sample mass or (2) the mean blank value plus 3 times the standard deviation and then divided by the sample mass. The maximum LODs are given in Table A2, Supplementary data.

To determine if the colonies were statistically different, Multivariate Analysis of Variance (MANOVA) was conducted on the log-transformed wet mass values (to meet normality assumptions) to control for Type 1 error that may occur if multiple individual ANOVAs were conducted. Due to limited degrees of freedom, groups were summed (BDEs, PCBs, dichlorodiphenyltrichloroethanes [DDTs], hexachlorocyclohexanes [HCHs], and chlordanes); hexachlorobenzene [HCB], dieldrin and mirex were individually added. If statistically different $(P<0.05)$, individual ANOVAs and Tukey-Kramer post-hoc tests were used to determine which locations were statistically different. Due to the differences in the sample sizes ( 5 for the Gulf of California, 18 for Crab Bank, SC and 10 for Marsh Island, SC) that may have affected the first MANOVA, the tests were repeated using the means of 3 egg "virtual pools" for the South Carolina samples. These pools were created by grouping by colony and clutch size and then random assignment to create 6 samples for Crab Bank and 3 for Marsh Island (see Table A1, Supplementary data for sample groupings). The MANOVA and post-hoc tests were repeated as for the individual samples. Principal components analysis was conducted on the percentage of total of all the individual compounds (see Table A2, Supplementary data for list) to help visualize any pattern of the contaminant differences. The individual BDE congeners and PCB homologue groups were also examined using ANOVAs and Tukey-Kramer post-hoc tests on both a mass fraction and percent of the total basis. ANOVAs and Tukey-Kramer post-hoc tests were also used to test the morphological differences of the eggs. For these comparisons, size index was calculated as length $\times$ breadth to approximate volume as used by Anderson and Hickey (1970) and thickness index was calculated as eggshell mass $\times 10 /$ (length $\times$ breadth) as used by Ratcliffe (1967). Statistical tests were conducted using commercially available software (SAS Institute, JMP 7.0.2, Cary, NC, USA).

\section{Results and discussion}

\subsection{Contaminant results}

The murre egg control material values were within previously reported ranges indicating that the analyses were in control. The three duplicate samples had percent differences that were generally $<10 \%$ indicating that the processing resulted in homogeneous samples and that analyses were reproducible (Table A2, Supplementary data). Hence, the mean of the replicates is reported hereafter.

The brown pelican eggs had mass fractions ranging from below detection limit to $1180 \mathrm{ng} \mathrm{g}^{-1}$ wet mass for $4,4^{\prime}$-DDE in sample CA-1 (Table 1 and Tables A3-A5, Supplementary data). There was considerable variation within colonies (overall relative standard deviation [RSD] had a mean \pm SD of $74.8 \% \pm 29.8 \%$ with a range of $14 \%$ to $260 \%$ with Gulf of California, Crab Bank, SC and Marsh Island, SC colony RSDs shown in Tables A3-A5, Supplementary data, respectively).

Two South Carolina samples, 21-05 and 15-05, had high levels of most contaminants (Tables A4 and A5, Supplementary data) and data from each were originally listed as outliers for Crab Bank and Marsh Island, respectively. However, even after removal, the colonies were not normally distributed. Therefore, these samples were re-included, the values were log-transformed, and subsequently the colonies were log-normally distributed allowing parametric statistical tests to be performed. Egg 23-05 had very high mass fractions and proportions of the lower chlorinated PCBs. Fortunately this sample was randomly chosen for the duplicate analysis (Table A2, Supplementary data), so the values obtained apparently are correct, even though it appears as an outlier on the principal components analysis (Fig. 1). This egg was found outside a nest (Table A1, Supplementary data), but the other two eggs collected from outside a nest (21-05 and 22-05) did not exhibit a similar pattern (Fig. 1 and Table A4, Supplementary data).
Brown pelican eggs from Marsh Island were at least an order of magnitude lower than those reported for eggs collected from this location in the 1970s for DDTs ([38.8-541] $\mathrm{ng} \mathrm{g}^{-1}$ vs. [360-11,190] ng $\mathrm{g}^{-1}$ ), dieldrin ([5.43-39.6] $\mathrm{ng} \mathrm{g}^{-1}$ vs. $\left.[<100-2890] \mathrm{ng} \mathrm{g}^{-1}\right)$, and PCBs ([172-1490] $\mathrm{ng} \mathrm{g}^{-1}$ vs. [700-36,500] $\mathrm{ng} \mathrm{g}^{-1}$; see Table 1) (Blus, 1982). Similarly, DDT in the eggs from the Gulf of California were an order of magnitude lower than those reported previously ([2.7-13.6] $\mu \mathrm{g} \mathrm{g}^{-1}$ lipid mass vs. [96.1-1204] $\mu \mathrm{g} \mathrm{g}^{-1}$ lipid mass) (Anderson et al., 1975). Based on the maximum residue reported by Blus (1982) that still resulted in nest success for PCBs $\left(18,600 \mathrm{ng} \mathrm{g}^{-1}\right)$, DDTs (4840 $\mathrm{ng} \mathrm{g}^{-1}$ ), and dieldrin (940 $\mathrm{ng} \mathrm{g}^{-1}$ ), current levels are well below those determined to adversely affect reproduction in brown pelicans.

As a class of emerging concern, the BDE data were further analyzed by comparing percentage of the individual congeners to the total BDEs (Fig. 2). BDE 47 was the major congener (mean \pm SD: $65.0 \% \pm 2.88 \%$, range: $61.0 \%$ to $72.1 \%$ ), followed by $\mathrm{BDE} 100(18.0 \% \pm 1.78 \% ; 13.3 \%$ to $21.2 \%$ ). The remaining congeners had mean compositions of less than $5 \%$ of the total. This pattern is identical to that recently reported for brown pelican eggs from the Chesapeake Bay region along the midAtlantic coast of the USA (Chen et al., 2010). The same study reported nearly identical levels of total BDEs as the South Carolina brown pelican eggs (median $27.5 \mathrm{ng} \mathrm{g}^{-1}$ wet mass with a range of $6.8 \mathrm{ng} \mathrm{g}^{-1}$ to $67.9 \mathrm{ng} \mathrm{g}^{-1}$ wet mass; see Table 2 for comparison). These levels are far below those reported to have toxicological effects (lowest observable effect level [LOEL] $\geq 1000 \mathrm{ng} \mathrm{g}^{-1}$ ) (Chen and Hale, 2010).

\subsection{East versus West comparisons}

The eggshell morphometrics between the South Carolina and Gulf of California eggs followed the pattern observed by Anderson and Hickey (1970) with no differences in shell size index, but significantly $(P<0.0001)$ lower eggshell masses and hence thickness indices in eggs from South Carolina (Table 2). While eggshells from both regions were still $1 \%$ to $5 \%$ thinner and lighter than those collected before the use of DDT in 1943, they were thicker and heavier than those collected in the 1950 s and 1960 s, the latter being $12 \%$ to $29 \%$ less than the pre-DDT eggshells (Anderson and Hickey, 1970).

A MANOVA comparing the contaminants in the Gulf of California and South Carolina eggs revealed significant differences (Wilks' $\lambda=0.0167$, $\left.F_{16,46}=19.4, P<0.0001\right)$. Brown pelican eggs from the Gulf of California had significantly $(P<0.05)$ lower concentrations of $\Sigma$ chlordanes, $\Sigma$ PCBs, dieldrin, and mirex and significantly higher levels of $\Sigma$ DDTs and $\Sigma$ HCHs compared to the South Carolina colonies while HCB was not significantly different (Table 1). The MANOVA for the "virtual pools" was still significant (Wilks' $\lambda=0.00575, \mathrm{~F}_{16,8}=6.09, P=0.0071$ ) and only the TukeyKramer post-hoc test for $\mathrm{ZPCBs}$ was different; this test no longer separated Gulf of California and South Carolina samples although the ANOVA was still significant ( $P=0.0467$; Table 1$)$. Thus pooling samples did not result in much statistical difference and may be a valid option for large sample sizes where the individual data are not required. Similar lack of statistical difference for individual versus pooled samples have previously been shown for guillemot (Uria lomvia) (Sellström et al., 2003) and herring gull (Larus argentatus) eggs (Turle and Collins, 1992).

The patterns of contaminants clearly separated the Gulf of California brown pelican eggs from the South Carolina eggs (Fig. 1). The first three principal components accounted for $72.7 \%$ of the total variation. Most eggs were well grouped within the respective colonies with the exception of egg 23-05 from Crab Bank, SC. This egg was collected from outside of a nest and had very high proportions of lower chlorinated PCBs ( $\leq 4$-Cl-PCBs were $32 \%$ of the total PCBs compared to $<10 \%$ for the other samples). The Gulf of California eggs contained significantly $(\mathrm{P}<0.05)$ higher proportions of all DDTs (except 2,4'-DDT/4,4'-DDD was not significantly different), $\mathrm{HCHs}, \mathrm{HCB}$, and BDEs $28,47,99$, and 100 and lower proportions of all PCBs (except 28/31 and 44 which were not significantly different), BDE 155 , all chlordane compounds, 
Table 1

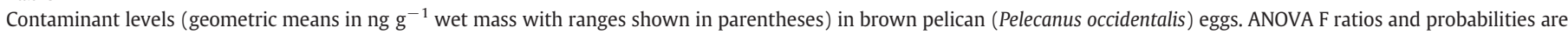

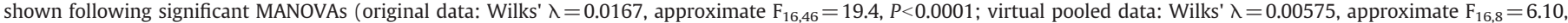

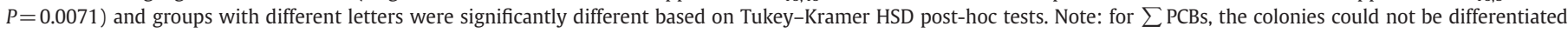
by the post-hoc test for the virtual pooled data.

\begin{tabular}{|c|c|c|c|c|c|c|c|}
\hline \multirow{2}{*}{$\begin{array}{l}\mathrm{N} \\
\text { Compound }\end{array}$} & \multicolumn{2}{|c|}{ Crab Bank, South Carolina } & \multicolumn{2}{|c|}{ Marsh Island, South Carolina } & \multirow{2}{*}{$\frac{\text { Gulf of California }}{5 \text { pools of } 3}$} & \multicolumn{2}{|c|}{ F ratio probability } \\
\hline & 18 & 6 virtual pools of 3 & 10 & 3 virtual pools of 3 & & $\begin{array}{l}33 \\
\text { Original data }\end{array}$ & $\begin{array}{l}14 \\
\text { Virtual pooled }\end{array}$ \\
\hline ¿Chlordanes & $\begin{array}{l}43.2^{\mathrm{A}} \\
(22.8-148)\end{array}$ & $\begin{array}{l}48.7^{\mathrm{A}} \\
(31.8-70.7)\end{array}$ & $\begin{array}{l}35.8^{\mathrm{A}} \\
(11.0-118)\end{array}$ & $\begin{array}{l}44.6^{\mathrm{A}} \\
(30.2-66.5)\end{array}$ & $\begin{array}{l}13.6^{\mathrm{B}} \\
(6.20-25.1)\end{array}$ & $\begin{array}{l}7.70 \\
0.0020^{*}\end{array}$ & $\begin{array}{l}10.4 \\
0.0029 *\end{array}$ \\
\hline ¿DDTs & $\begin{array}{l}132^{\mathrm{B}} \\
(53.8-466)\end{array}$ & $\begin{array}{l}150^{\mathrm{B}} \\
(96.6-215)\end{array}$ & $\begin{array}{l}119^{\mathrm{B}} \\
(38.8-541)\end{array}$ & $\begin{array}{l}158^{\mathrm{B}} \\
(104-266)\end{array}$ & $\begin{array}{l}489^{\mathrm{A}} \\
(223-1210)\end{array}$ & $\begin{array}{l}9.93 \\
0.0005^{*}\end{array}$ & $\begin{array}{l}9.26 \\
0.0044^{*}\end{array}$ \\
\hline$\Sigma \mathrm{HCHs}$ & $\begin{array}{l}1.05^{\mathrm{B}} \\
(0.542-3.42)\end{array}$ & $\begin{array}{l}1.15^{\mathrm{B}} \\
(0.812-2.20)\end{array}$ & $\begin{array}{l}0.830^{\mathrm{B}} \\
(0.486-1.30)\end{array}$ & $\begin{array}{l}0.914^{\mathrm{B}} \\
(0.725-1.05)\end{array}$ & $\begin{array}{l}13.6^{\mathrm{A}} \\
(6.46-36.7)\end{array}$ & $\begin{array}{l}61.3 \\
<0.0001^{*}\end{array}$ & $\begin{array}{l}43.0 \\
<0.0001^{*}\end{array}$ \\
\hline ¿PBDES & $\begin{array}{l}25.8 \\
(10.6-66.6)\end{array}$ & $\begin{array}{l}29.1 \\
(15.6-48.8)\end{array}$ & $\begin{array}{l}25.3 \\
(10.2-69.8)\end{array}$ & $\begin{array}{l}30.0 \\
(22.3-44.4)\end{array}$ & $\begin{array}{l}61.5 \\
(11.7-262)\end{array}$ & $\begin{array}{l}2.96 \\
0.0669\end{array}$ & $\begin{array}{l}1.15 \\
0.351\end{array}$ \\
\hline$\Sigma \mathrm{PCBS}$ & $\begin{array}{l}565^{\mathrm{A}} \\
(262-1800)\end{array}$ & $\begin{array}{l}620^{A} \\
(444-940)\end{array}$ & $\begin{array}{l}512^{\mathrm{A}} \\
(162-1490)\end{array}$ & $\begin{array}{l}628^{A} \\
(491-941)\end{array}$ & $\begin{array}{l}135^{\mathrm{B}(\mathrm{A})} \\
(28.6-945)\end{array}$ & $\begin{array}{l}7.60 \\
0.0021^{*}\end{array}$ & $\begin{array}{l}4.10 \\
0.0467^{*}\end{array}$ \\
\hline Dieldrin & $\begin{array}{l}16.7^{\mathrm{A}} \\
(9.26-56.8)\end{array}$ & $\begin{array}{l}18.2^{\mathrm{A}} \\
(13.3-27.2)\end{array}$ & $\begin{array}{l}15.0^{\mathrm{AB}} \\
(5.43-39.6)\end{array}$ & $\begin{array}{l}17.8^{\mathrm{AB}} \\
(13.8-24.9)\end{array}$ & $\begin{array}{l}5.42^{\mathrm{B}} \\
(3.15-9.96)\end{array}$ & $\begin{array}{l}3.92 \\
0.0306^{*}\end{array}$ & $\begin{array}{l}6.27 \\
0.0152^{*}\end{array}$ \\
\hline $\mathrm{HCB}$ & $\begin{array}{l}1.54 \\
(0.819-3.66)\end{array}$ & $\begin{array}{l}1.68 \\
(1.42-2.29)\end{array}$ & $\begin{array}{l}1.45 \\
(0.563-3.60)\end{array}$ & $\begin{array}{l}1.76 \\
(1.29-2.44)\end{array}$ & $\begin{array}{l}2.73 \\
(1.06-5.16)\end{array}$ & $\begin{array}{l}2.93 \\
0.0687\end{array}$ & $\begin{array}{l}2.10 \\
0.1694\end{array}$ \\
\hline Mirex & $\begin{array}{l}5.53^{\mathrm{A}} \\
(2.56-14.2)\end{array}$ & $\begin{array}{l}6.21^{\mathrm{A}} \\
(4.14-8.73)\end{array}$ & $\begin{array}{l}4.80^{\mathrm{A}} \\
(1.92-18.6)\end{array}$ & $\begin{array}{l}6.08^{\mathrm{A}} \\
(4.02-10.6)\end{array}$ & $\begin{array}{l}0.287^{\mathrm{B}} \\
(0.146-0.629)\end{array}$ & $\begin{array}{l}59.2 \\
<0.0001^{*}\end{array}$ & $\begin{array}{l}65.1 \\
<0.0001^{*}\end{array}$ \\
\hline
\end{tabular}

dieldrin, and mirex than the South Carolina eggs. The only significant differences between the South Carolina colonies were higher proportions of BDE 155, and PCBs 154, 178, and 187 at Marsh Island than at Crab Bank.

The Gulf of California brown pelican eggs had significantly $(P<0.05)$ higher mass fractions of the lower brominated BDE congeners $(28,47$, 66,99 , and 100) compared to the South Carolina eggs while BDE congeners 153,154 , and 155 were not statistically different (Fig. 2). The proportions of these congeners to the total also followed a similar pattern with the exception of BDE 28 not being significantly different and BDE 100 had higher proportions in the South Carolina eggs. This is believed to be the first study of flame retardants in the Gulf of California, so it is uncertain if this pattern is indicative of the local ecosystem. However, based on the California state government requirements that furniture and bedding sold in the state be flame-retardant (State of California, 2011), it is not surprising that this increased consumer use of BDEs has affected the wildlife in the region.

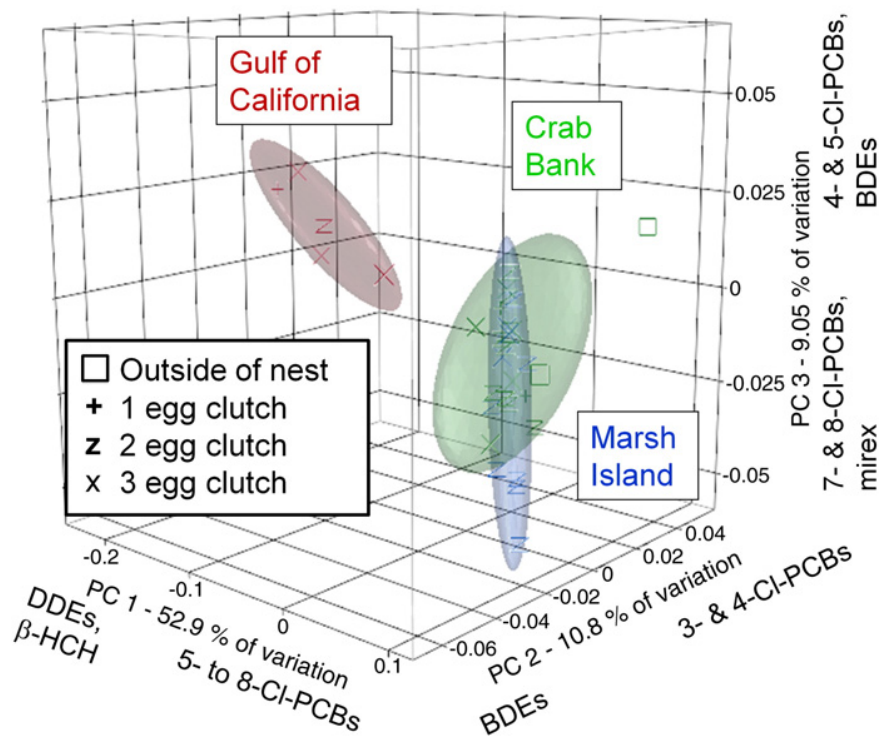

Fig. 1. Principal components analysis of brown pelican (Pelecanus occidentalis) eggs from Gulf of California, Mexico and South Carolina, USA. Compounds contributing to the loadings are shown along the axes.
Polychlorinated biphenyl homologue groups were also investigated further for differences among the colonies. This time the lower chlorinated groups showed no statistical differences in either the mass fractions or proportions to the total PCBs (Fig. 3). The hexaPCBs comprised a greater proportion of total PCBs in the Gulf of California brown pelican eggs compared to the South Carolina eggs, while the latter had higher proportions of the hepta- and octa-PCBs. The Marsh Island, South Carolina eggs also had significantly greater mass fractions of the octa-PCBs than the Gulf of California eggs. While studies on PCBs in loggerhead turtles (Caretta caretta) have occurred both in the Gulf of California and Cape Romain NWR South Carolina, the tissues examined differed with liver in the former and eggs and chorioallantoie membranes (CAM) in the latter and a decade elapsed between studies (Cobb and Wood, 1997; Richardson et al., 2010). However, as no other studies were as similar for the regions, the proportions of the PCBs to the total contribution were compared based on the means reported. The Gulf of California turtles had

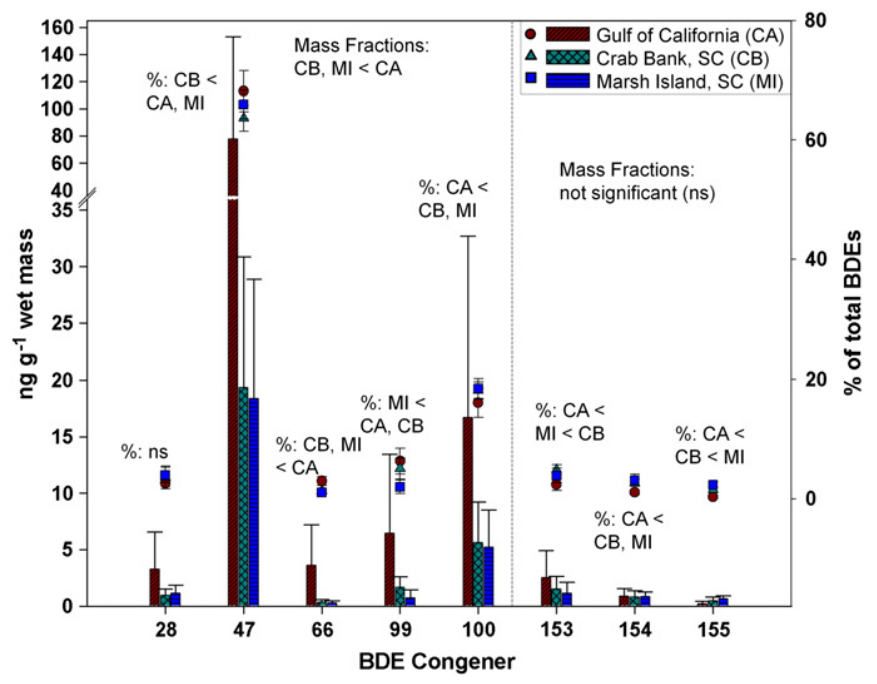

Fig. 2. Mean \pm 1 standard deviation of mass fractions (ng $\mathrm{g}^{-1}$ wet mass) and percentage of total brominated diphenyl ether (BDE) congeners in brown pelican (Pelecanus occidentalis) eggs. All the percentages, except BDE 28, had significant ANOVAs $(P<0.05)$. Tukey-Kramer HSD post-hoc test results are shown for colony differences. Mass fractions of BDE congeners 153, 154, and 155 were not significant; the rest had significantly higher values in the Gulf of California eggs. See Table A1 Supplementary data for sample information. 
Table 2

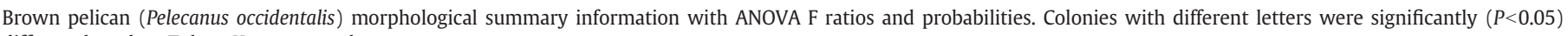
different based on Tukey-Kramer post-hoc tests.

\begin{tabular}{|c|c|c|c|c|}
\hline & Crab Bank, South Carolina & Marsh Island, South Carolina & Gulf of California & F ratio probability \\
\hline $\mathrm{N}$ & 18 & 10 & 15 & 43 \\
\hline \multicolumn{5}{|l|}{ Measurement } \\
\hline \multirow[t]{2}{*}{ Whole egg (g) } & 99.3 & 97.5 & 97.3 & 0.225 \\
\hline & $(88.2-117.5)$ & $(82.8-115.2)$ & $(75.5-111.5)$ & 0.7994 \\
\hline \multirow[t]{2}{*}{ Eggshell (g) } & $9.2^{\mathrm{B}}$ & $8.5^{\mathrm{B}}$ & $10.3^{\mathrm{A}}$ & 11.9 \\
\hline & $(7.2-11.4)$ & $(7.0-9.2)$ & $(8.9-11.8)$ & $<0.0001^{*}$ \\
\hline \multirow[t]{2}{*}{ Length $(\mathrm{cm})$} & 7.68 & 7.42 & 7.63 & 2.00 \\
\hline & $(6.98-8.24)$ & $(6.96-7.77)$ & $(6.95-8.58)$ & 0.1489 \\
\hline \multirow[t]{2}{*}{ Breadth $(\mathrm{cm})$} & 4.92 & 4.96 & 5.00 & 1.60 \\
\hline & $(4.71-5.29)$ & $(4.77-5.25)$ & $(4.76-5.18)$ & 0.2138 \\
\hline \multirow[t]{2}{*}{ Size index $\left(\mathrm{cm}^{2}\right)$} & 37.8 & 36.8 & 38.1 & 1.19 \\
\hline & $(34.2-41.8)$ & $(34.1-40.8) 0$ & $(33.1-42.8)$ & 0.3153 \\
\hline \multirow[t]{2}{*}{ Thickness index } & $2.44^{\mathrm{B}}$ & $2.32^{\mathrm{B}}$ & $2.71^{\mathrm{A}}$ & 12.1 \\
\hline & $(2.07-2.86)$ & $(1.92-2.62)$ & $(2.28-2.97)$ & $<0.0001^{*}$ \\
\hline
\end{tabular}

slightly higher proportion of hexa-PCBs ( $41.4 \%$ vs. $27.2 \%$ in the eggs and $35.4 \%$ in the CAM), similar to the brown pelican eggs. However the opposite trend was observed for penta-PCBs with lower proportions in the Gulf of California turtles (23.0\% vs. $30.1 \%$ in the eggs and $37.0 \%$ in the CAM) and higher proportions of the octa-PCBs (3.6\% vs. $2.0 \%$ in the eggs and $3.6 \%$ in the CAM). Aside from the confounding factors of different tissues and the temporal differences, the PCB congeners used in these studies may also have differed affecting the ability to truly make accurate comparisons, again indicating that more work is needed in determining contaminant levels in both of these regions. There is a superfund site south of the South Carolina colonies in Brunswick, GA that used Aroclor 1268, which is uniquely comprised of higher chlorinated PCBs, and surrounding wildlife has been found to reflect this unique PCB pattern (Kannan et al., 1998), which may help explain the higher proportion of these compounds in the South Carolina eggs compared to the Gulf of California eggs (Fig. 3), although this was not reflected as strongly in the turtle eggs and CAM collected from the same region in 1993.

Overall, there are clearly differences in contaminants between the east and the west populations of brown pelicans. While contaminant levels should be below those causing an effect on the population levels, the different trajectories of the population sizes was a driver in

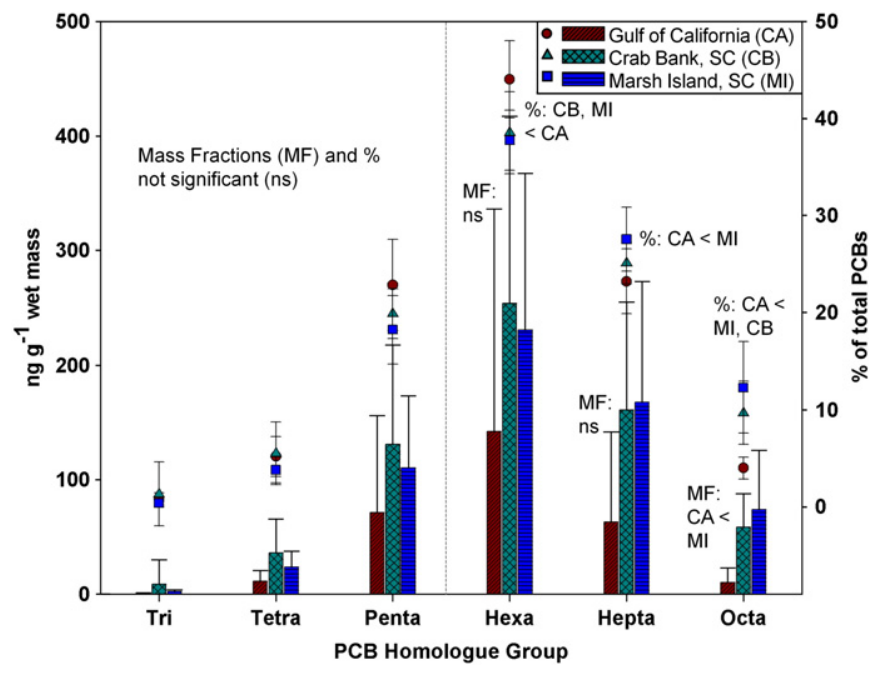

Fig. 3. Mean \pm 1 standard deviation of mass fractions ( $\mathrm{ng} \mathrm{g}^{-1}$ wet mass) and percentage of total polychlorinated biphenyl (PCB) homologue groups in brown pelican (Pelecanus occidentalis) eggs. Only the higher chlorinated $\mathrm{PCB}$ homologue groups had significant ANOVAs $(P<0.05)$ for the percentage of total PCBs. Tukey-Kramer HSD post-hoc test results are shown for colony differences. Mass fractions were significantly different for only the octa-PCBs with Gulf of California eggs having lower values than Marsh Island, South Carolina eggs. See Table A1, Supplementary data for sample information. undertaking this study (Anderson et al., 2007; Jodice et al., 2007; Watts and Byrd, 2006), so the observed differences between the populations is still intriguing and worthy of further study. Explanations for these differences cannot be readily obtained, but one may suspect that proximity to industrial sources or areas of use would be the main reason. Unfortunately, very little data is available to compare and contrast either the sources of contamination or other studies that have data for similar species and similar times. One other source of data that is available for both the Gulf of California region and the South Carolina region is the Mussel Watch Program which conducted a special international assessment that included mussels from San Felipe, Mexico in 1992 (International Mussel Watch Committee, 1995). These data were compared to data for oysters from Charleston, South Carolina also collected in 1992 (Center for Coastal Monitoring and Assessment, 2011). While $\Sigma$ chlordanes, $\Sigma$ PCBs, dieldrin, and mirex were significantly higher in brown pelicans from South Carolina (Table 1), the Mussel Watch data had similar levels for these compounds at both locations, with the exception of dieldrin where the South Carolina oysters had [3.76 and 4.24] ng g ${ }^{-1}$ dry mass while the Gulf of California mussels were below the detection limit of $0.25 \mathrm{ng} \mathrm{g}^{-1}$ dry mass. The east coast oysters also had higher levels of DDTs ([24.9 and 29.4] $\mathrm{ng} \mathrm{g}^{-1}$ dry mass), and $\gamma-\mathrm{HCH}$ ([1.93 and 1.98] $\mathrm{ng} \mathrm{g}^{-1}$ dry mass) compared to the Gulf of California mussels ([9.18 and $<0.25]$ ng g $^{-1}$ dry mass, respectively), opposite of the trend for the brown pelicans (Table 1). Unfortunately many of the compounds studied in the Mussel Watch were below detection limits or at trace levels so more thorough comparisons were not possible for the PCB homologue group patterns or even major compounds to the sum of the classes (brown pelican egg data are shown in Figs. 3 and A1, Supplementary data, respectively). BDEs were also not measured in the special international collection, but in 2004, BDE 47 was measured in southern California mussel tissue and ranged from [6.8 to 777] $\mathrm{ng} \mathrm{g}^{-1}$ dry mass while South Carolina oyster tissue in 2004 ranged from [ 0.7 to 4.9 ] $\mathrm{ng} \mathrm{g}^{-1}$ dry mass which did follow the pattern observed for the brown pelicans (Fig. 2) (Center for Coastal Monitoring and Assessment, 2011).

\section{Conclusions}

This is the first known study to directly examine contamination differences between the southeast United States and the Gulf of California, as well as the first known one to examine BDEs in the latter ecosystem. Brown pelicans in these regions have very different population trends and may be useful biomonitors in these ecosystems. While eggs from the Gulf of California had higher levels of lower brominated BDEs, DDTs, and HCHs, South Carolina eggs had higher levels of PCBs, chlordanes, dieldrin and mirex. The patterns of the contaminants also varied between the regions. More research is needed to clearly understand the differences in the east and west coast populations and ecosystem 
contamination patterns. Future research is needed in both of these ecosystems to examine these contaminants in the prey fish and other top predators. Examination of current use of pesticides and other contaminants of emerging concern, such as perfluorinated chemicals or other flame retardants, and stable isotopes or fatty acid analyses may also help elucidate the differences in the brown pelican population status between the Gulf of California and the southeast United States.

\section{Acknowledgements}

The authors would like to thank James Keith, Carlos Godínez-Reyes, Enriqueta Velarde, Kirke King, Karina Santos del Prado, Lawrence De Weese, Eduardo Palacios, Lisa Eggert, Margie Peden-Adams, Jennifer Keller, and John Kucklick for their assistance with these projects and Miguel Mora for providing a critical review of this manuscript.

For the South Carolina eggs, logistical and administrative support was provided by SC DNR and Cape Romain NWR. The South Carolina Cooperative Fish and Wildlife Research Unit is supported jointly by the U.S. Geological Survey, South Carolina Department of Natural Resources, Clemson University, and the U.S. Fish and Wildlife Service. For the Gulf of California eggs, collecting permits were issued to the office of Area de Protección de Flora y Fauna Islas del Golfo de California, “Comisión Nacional de Áreas Natrurales Protegidas: (CONANP, see Godínez Reyes et al. (2006)). Support was provided by the University of California, Davis; Agricultural Experiment Station. NIST supported the analysis of all egg samples for organic contaminants.

\section{Disclaimer}

Any mention of commercial products is for information only; it does not imply recommendation or endorsement by NIST or any other U.S. Government agency.

\section{Appendix A. Supplementary data}

Supplementary data associated with this article can be found in the online version, at http://dx.doi.org/10.1016/j.scitotenv.2012.08. 055. These data include Google maps of the most important areas described in this article.

\section{References}

Anderson DW, Hickey JJ. Oological data on egg and breeding characteristics of brown pelicans. Wilson Bull 1970;82:14-28.

Anderson DW, Jehl Jr JR, Risebrough RW, Woods Jr Leon A, Deweese LR, Edgecomb WG. Brown pelicans: improved reproduction off the southern California coast. Science 1975;190:806-8.

Anderson DW, Henny CJ, Godinez-Reyes C, Gress F, Palacios EL, Santos del Prado K, et al. Size of the California brown pelican metapopulation during a non-El Niño year. Reston, Virginia: U.S. Geological Survey; 2007. p. 35. http://fresc.usgs.gov/products/ papers/of_07_1299.pdf.

Blus LJ. Further interpretation of the relation of organochlorine residues in brown pelican eggs to reproductive success. Environ Pollut Ser A 1982;28:15-33.

Bureau of Sport Fisheries and Wildlife, Fish and Wildlife Service, Department of the Interior. Part 17-Conservation of endangered species and other fish and wildlife. Fed Regist 1970;35(106):8491-8. (http://ecos.fws.gov/docs/federal_register/fr21.pdf).

Center for Coastal Monitoring and Assessment. NS\&T program download page. http:// ccma.nos.noaa.gov/about/coast/nsandt/download.aspx 2011.

Chen D, Hale RC. A global review of polybrominated diphenyl ether flame retardant contamination in birds. Environ Int 2010;36:800-11.
Chen D, Hale RC, Watts BD, La Guardia MJ, Harvey E, Mojica EK. Species-specific accumulation of polybrominated diphenyl ether flame retardants in birds of prey from the Chesapeake Bay region, USA. Environ Pollut 2010;158:1883-9.

Cobb GP, Wood PD. PCB concentrations in eggs and chorioallantoic membranes of loggerhead sea turtles (Caretta caretta) from the Cape Romain National Wildlife Refuge. Chemosphere 1997;34:539-49.

Eustis CE, Department of the Interior, Fish and Wildlife Service. Endangered and threatened wildlife and plants; removal of the brown pelican (Pelecanus occidentalis) from the federal list of endangered and threatened wildlife. Fed Regist 2009;74(220):59444-72. (http://www.gpo.gov/fdsys/pkg/FR-2009-11-17/pdf/E9-27402.pdf\#page=1).

Godínez Reyes C, Santos del Prado Gasca K, Zepeda López H, Aguirre A, Anderson DW, Parás González A, et al. Monitoreo de poblaciones y condición de salud de aves marinas y lobos marinos en islas del norte del Golfo de California, México. Gac Ecol 2006;81:31-45.

Gottschalk JS, Bureau of Sport Fisheries and Wildlife, Fish and Wildlife Service, Department of the Interior. Appendix D-United States list of endangered native fish and wildlife. Fed Regist 1970;35(199):16047-8. (http://ecos.fws.gov/docs/federal_register/fr27.pdf).

International Council for the Exploration of the Sea (ICES). Seabirds as monitors of the marine environment. ICES Cooperative Research Report, 258; 2003. p. 73. http:// biblio.uqar.qc.ca/archives/1008207.pdf.

International Mussel Watch Committee. International Mussel Watch Project: initial implementation phase final report. Silver Spring, Maryland: NOAA Office of Ocean Resources Conservation and Assessment, National Ocean Service; 1995. p. 174. http://www.ccma.nos.noaa.gov/publications/tm95.pdf.

Jodice PGR, Murphy TM, Sanders FJ, Ferguson LM. Longterm trends in nest counts of colonial seabirds in South Carolina, USA. Waterbirds 2007;30:40-51.

Kannan K, Nakata H, Stafford R, Masson GR, Tanabe S, Giesy JP. Bioaccumulation and toxic potential of extremely hydrophobic polychlorinated biphenyl congeners in biota collected at a superfund site contaminated with Aroclor 1268. Environ Sci Technol 1998;32:1214-21.

Potter JC, Department of the Interior, Fish and Wildlife Service. Endangered and threatened wildlife and plants; removal of the brown pelican in the southeastern United States from the list of endangered and threatened wildlife. Fed Regist 1985;50(23): 4938-45. (http://ecos.fws.gov/docs/federal_register/fr919.pdf).

Ratcliffe DA. Decrease in eggshell weight in certain birds of prey. Nature 1967;215: 208-10.

Richardson K, Lopez Castro M, Gardner S, Schlenk D. Polychlorinated biphenyls and biotransformation enzymes in three species of sea turtles from the Baja California peninsula of Mexico. Arch Environ Contam Toxicol 2010;58:183-93.

Roseneau DG, Becker PR, York GS, Vander Pol SS, Day RD, Point D, et al. Expanding the Seabird Tissue Archival and Monitoring Project (STAMP) in the North Pacific: geographic patterns in contaminant residues in seabird eggs used in rural subsistence diets. Vol Project 2008;0534:145.

Sellström U, Bignert A, Kierkegaard A, Häggberg L, de Wit CA, Olsson M, et al. Temporal trend studies on tetra- and pentabrominated diphenyl ethers and hexabromocyclododecane in guillemot egg from the Baltic Sea. Environ Sci Technol 2003;37:5496-501.

Shields M. Brown pelican (Pelecanus occidentalis). In: Poole A, editor. The birds of North America online, 609. Ithaca: Cornell Lab of Ornithology; 2002. http://bna birds.cornell.edu/bna/species/609/articles/introduction.

State of California. Department of Consumer Affairs Bureau of Electronic and Appliance Repair, home furnishings and thermal insulation technical bulletins. http://www. bhfti.ca.gov/industry/bulletin.shtml 2011. (accessed 25 April 2012).

Turle R, Collins B. Validation of the use of pooled samples for monitoring of contaminants in wildlife. Chemosphere 1992;25:463-9.

US Environmental Protection Agency. Polybrominated diphenyl ethers (PBDEs) action plan summary. http://www.epa.gov/opptintr/existingchemicals/pubs/actionplans/ pbde.html\#action 2012. (accessed 25 April 2012).

Vander Pol SS, Ellisor MB, Pugh RS, Becker PR, Poster DL, Schantz MM, et al. Development of a murre (Uria spp.) egg control material. Anal Bioanal Chem 2007;387: 2357-63.

Vander Pol SS, Becker PR, Ellisor MB, Moors AJ, Pugh RS, Roseneau DG. Monitoring organic contaminants in eggs of glaucous and glaucous-winged gulls (Larus hyperboreus and Larus glaucescens) from Alaska. Environ Pollut 2009;157:755-62.

Vander Pol SS, Kucklick JR, Leigh SD, Porter BJ, Schantz MM. Separation of 26 toxaphene congeners and measurement in air particulate matter SRMs compared to technical toxaphene SRM 3067. Anal Bioanal Chem 2010;397:483-92.

Vander Pol SS, Hobson KA, Becker PR, Day RD, Ellisor MB, Pugh RS, et al. Geographic differences in organic contaminants and stable isotopes $\left(\delta^{13} \mathrm{C}, \delta{ }^{15} \mathrm{~N}\right)$ in thick-billed murre (Uria lomvia) eggs from Alaska. J Environ Monit 2011;13:699-705.

Watts BD, Byrd MA. Status and distribution of colonial waterbirds in coastal Virginia: the 2003 breeding season. The Raven 2006;77:3-22. 